\title{
Impaired Social Interaction in Autism Spectrum Disorders
}

\section{Kunio Yui*}

Research Institute of Pervasive Developmental Disorders, Hyogo, Japan

Autism spectrum disorders (ASD) are characterized by impairment in social reciprocity, disturbances in language and communication, restricted interests and repetitive behaviors of various types, as defined by the DSM-IV [1]. Currently, no drug has been consistently proven to be effective for the core social and communication impairment so central to the PDDs. Pharmacotherapy in ASD lacks a solid, reliable neurobiological basis and at present it is mainly directed at the socalled associated behavioral symptoms, with limited relevance to core symptoms. Atypical neuroleptics, especially risperidone, have been shown to be useful in the treatment of behavioral symptoms in ASD. Recent trials with SSRIs did not show remarkable results, in spite of their promising potential role [2,3]. Research is now directed at evaluating novel treatments and combined behavioral and pharmacologic treatments, since behavioral interventions are the mainstay of the early treatment of autism.

Abnormal functional connectivity, which affects the delivery of afferent signals, may be involved in the pathophysiology of ASD [4]. Alternatively, individuals with ASD may be more vulnerable to oxidative stress due to deficit antioxidant defense mechanisms [5]. Polyunsaturated fatty acids, arachidonic acid (ARA) and Docosahexaenoic acid (DHA) play key roles in brain network maturation. ARA is important for signal transduction [6]. Therefore, it is clear that supplements containing antioxidants that are related to lipid peroxidation may be beneficial for individuals with ASD [7]. Previous double-blind randomized placebo-controlled studies have helped to validate the efficacy of DHA or eicosapentaenoic Acid (EPA) plus small doses of ARA (42 or $40 \mathrm{mg} /$ day) in reducing behavioral problems in Attention-Deficit/Hyperactive Disorders (AD/HD) [8] and learning difficulties (LD) [9]. However, there are few studies that have examined the effects of larger doses of ARA added to DHA on the core behavioral and social impairments of ASD with double-blind, randomized, placebo-controlled designs. We therefore examined the effect of supplementation with large doses of ARA added to DHA (240 $\mathrm{mg} /$ day) in individuals with ASD $(n=13)$ in a double-blind, placebocontrolled trial, followed by an open-label treatment. Daily doses of ARA and DHA were $240 \mathrm{mg}$ /day. Four participants aged 6-10 years received one-half of the daily doses of the supplementation (for a total of $120 \mathrm{mg}$ ARA and $120 \mathrm{mg}$ DHA per day). Previous studies of supplementation with PUFAs, ARA doses were $40 \mathrm{mg}$ /day [9] or 42 $\mathrm{mg} /$ day [8]. ARA doses used in this study were 120 or $240 \mathrm{mg} /$ day, and our supplementation included thus larger doses of ARA compared to these previous studies.

To investigate the mechanisms underlying the efficacy of our supplementation, we examined 1) transferrin (Tf) plasma levels, as $\mathrm{Tf}$ is an important transporter in brain signaling [10] and a part of the antioxidant defense mechanisms [11],2) superoxide dismutase (SOD) plasma levels, as SOD is a modifier of signaling process [12] and important in the defense against oxidative stress [13], and 3) ceruloplasmine $(\mathrm{Cp})$ plasma levels, as $\mathrm{Cp}$ is modifier of signaling and has a role in regulating oxidative stress [14]. The outcome measures were the Aberrant Behavior Checklist (ABC) and Social Responsiveness Scale (SRS). Our supplementation significantly improved ABC social withdrawal, and SRS communication subscales. There was a significant difference in the change in plasma Tf levels and a trend towards a significant difference in plasma SOD levels between the groups. The open-label treatment revealed no significant differences between the groups. No adverse effects were observed both in the placebocontrolled trial and the open-label treatment.

Our supplementation may improve impaired social interaction via activation of the signaling pathway and possibly through increased antioxidant capacity. The supplementation with large doses of ARA added to DHA may be used for children with ASD without any aversive effect, and attenuate behavioral interventions.

\section{References}

1. American Psychiatric Association (2000) Diagnostic and Statistical Manual of Mental Disorders, Fourth Edition: DSM-IV-TR囚. American Psychiatric Association, Washington DC, pp. 943.

2. Canitano R, Scandurra $\vee(2011)$ Psychopharmacology in autism: an update Prostgrandin Leukot Essent. Fatty Acids 32: 18-28.

3. Yui K, Nakamura S (2012) Neurobiological basis and pharmacologic treatment of social impairment in autism spectrum disorders. Curr Psychopharmacol 1 : 233-246.

4. Courchesne E, Pierce K, Schumann CM, Redcay E, Buckwalter JA, et al (2007) Mapping early brain development in autism. Neuron 56: 399-413.

5. Meguid N, Dardir AA, Abdel-Raouf ER, Hashish A (2011) Evaluation of Oxidative stress in autism: defective antioxidant enzymes and increased lipid peroxidation. Biol Trace Elem Res 143: 58-65.

6. Tamiji J, Crawford DA (2010) The neurobiology of lipid metabolism in autism spectrum disorders. Neurosignals 18: 98-112.

7. Villagonzalo KA, Dodd S, Dean O, Gray K, Tonge B, et al. (2010) Oxidative pathways as a drug target for the treatment of autism. Expert Opin TherTargets14: 1301-1310.

8. Richardson AJ, Puri BK (2002) A randomized double-blind, placebo- controlled study of the effects of supplementation with highly unsaturated fatty acids on ADHD-related symptoms in children with specific leaning difficulties. Prog NeuroPsychopharmacol bio Psychiatry26: 233-239.

9. Stevens L, Zhang W, Peck L, Kuczek T, Grevstand N, et al. (2003) EFA supplementation in children with inattention, hyperactivity, and other disruptive behaviors. Lipids 38: 1007-1021.

10. Kurlak L, Stephenson T (1999) Plausible explanations for effects of long-chain polyunsaturated fatty acids (LCPUFA) on neonates. Arch Dis Child Fetal Neonatal Ed 80: F148-F154.

11. Schulpis KH, Papastamataki M, Stamou H, Papassotirious I, Margeli A (2010) The effect of diet on total antioxidant status, ceruloplasmine, transferrin and ferrin serum levels in phenylketonuric children. Acta Paediatr 99: 1565-1570.

12. Louboutin JP, Agrawal L, Reyes BAS, van Bockataele EJ, Strayer S (2012) Gene delivery of antioxidant enzymes inhibits human immunodeficiency virus type 1 gene 120-1induced expression. Neuroscience 214: 66-77.

*Corresponding author: Kunio Yui, Research Institute of Pervasive Developmental Disorders, Tel: +81 78791 8981; E-mail: yui16@bell.ocn.ne.jp

Received August 28, 2013; Accepted August 31, 2013; Published September 05, 2013

Citation: Yui K (2013) Impaired Social Interaction in Autism Spectrum Disorders. J Socialomics 2: e120. doi:10.4172/2167-0358.1000e120

Copyright: (c) 2013 Yui K. This is an open-access article distributed under the terms of the Creative Commons Attribution License, which permits unrestricted use, distribution, and reproduction in any medium, provided the original author and source are credited. 
13. Yorbik O, Sayal A, Akay C, Akbiyi DI, Sohmen T (2002) Investigation of antioxidant enzymes in children with autistic disorder. Prostagland Leukot Essent Fatty Acids 67: 341-343
14. Das D, Tapryal N, Goswami SK, Fox PL, Mukhopadiyay CK (2007) Regulation of ceruloplasmine in human hepatic cells by redox active copper: identification of a novel AP-1 site in the ceruloplasmin gene. Biochem J 402: 135-141. 